\title{
Meningkatkan hasil belajar siswa kelas v menggunakan model corp horay pada materi keberagaman sosial budaya masyarakat Indonesia
}

\section{Improving student learning outcomes in grade $v$ using the corp horay model on the material of the socio-cultural diversity of Indonesian society}

\author{
Khairi $^{1}$ \\ ${ }^{1}$ SDN 3 Sungai Tiung \\ Email: khairispd86@guru.sd.belajar.id ${ }^{1}$
}

\section{INFO ARTIKEL}

Diterima : 30 April 2021

Disetujui : 27 Mei 2021

Tersedia secara Online Mei 2021

\author{
Alamat Korespondensi: \\ Khairi \\ SDN 3 Sungai Tiung \\ Jalan Transpol Kelurahan Sungai \\ Tiung Kecamatan Cempaka Kota \\ Banjarbaru \\ E-mail: \\ khairispd86@guru.sd.belajar.id
}

\begin{abstract}
ABSTRAK
Penelitian ini memiliki tujuan untuk mendeskripsikan aktivitas guru, aktivitas siswa serta menganalisis peningkatan hasil belajar siswa pada materi keberagaman sosial budaya masyarakat Indonesia. Penelitian ini menggunakan PTK dan dilaksanakan dalam 4 kali pertemuan dengan menggunakan kombinasi model CORP HORAY (Contekstual Teaching Learning, Role Playing, Course Review Horay). Pelaksanaan penelitian dilakukan pada kelas V SDN 3 Sungai Tiung Banjarbaru dengan total 15 siswa pada semester genap tahun ajaran 2019/2020. Hasil penelitian yang telah dilakukan menunjukkan aktivitas guru pada pertemuan I sampai IV secara berurutan memperoleh kriteria baik, sangat baik, sangat baik, dan pertemuan IV mencapai kriteria sangat baik. Untuk aktivitas siswa pada pertemuan I sampai IV perolehan persentase menunjukan 52\%, $67 \% 78 \%$ dan 95 . Untuk perolehan hasil belajar siswa pada pertemuan I sampai IV mencapai 44\%, 59\%, 78\%, dan 96\%. Penelitian ini memuat temuan berupa untuk aktivitas guru penelitian ini terlaksana dengan sangat baik, siswa sangat aktif, serta dapat membuat hasil belajar siswa meningkat dan mencapai ketuntasan secara individu bahkan secara klasikal menggunakan kombinasi model CORP HORAY.
\end{abstract}

Kata Kunci: Hasil Belajar, Keberagaman Sosial Budaya Masyarakat Indonesia, CORP HORAY.

This study describe the activities of teachers, student activities and analyze improvement of student learning outcomes in the material socio-cultural diversity of Indonesian society. This study uses CAR and was conducted in 4 meetings using a combination of CORP HORAY (Contextual Teaching Learning, Role Playing, Course Review Horay) models. The research was carried out in the fifth grade at SDN 3 Sungai Tiung, totaling 15 students in the 2019/2020 school year semester. The results of this study indicate that the activities of teachers at meetings I to IV in a row obtained good criteria, very good, very good, and meeting IV reached very good criteria. For student activities at meetings I to IV the percentage acquisition shows 52\%, $67 \% 78 \%$ and 95 . And the last acquisition of classical completeness student learning outcomes at meetings I to IV reached 44\%, 59\%, $78 \%$, and $96 \%$. This research contains findings in the form of activities for teachers of this research very well implemented, students are very active, and can make student learning outcomes improve and achieve completeness individually even classically using a combination of CORP HORAY models. 
Key Word: Learning Outcomes, socio-cultural diversity of Indonesian society,CORP HORAY.

\section{PENDAHULUAN}

Era globalisasi ini merupakan sebuah realitas yang harus dihadapi seluruh masyarakat di dunia, tidak terkecuali masyarat Indonesia. Aspek-aspek dalam kehidupan kehidupan manusia, dari kehidupan sosial, ekonomi, politik, budaya, hukum, pendidikan mengalami perubahan karena adanya globalisasi (Tilaar, 2005).

Dari penjelasan di atas pendidikan memiliki keterkaitan erat dengan adanya globalisasi. Pengaruh globalisasi terhadap pendidikan masa ini dengan seiring berbagai kemajuan dalam teknologi, berbagai nilai-nilai kesopanan, bahkan budi pekerti seakan telah diabaikan yang mengakibatkan banyak siswa yang mempunyai perilaku menyimpang. Hal itu dikarenakan krisis karakter bangsa. Untuk mengatasi permasalahan tersebut sangat dibutuhkan sebuah pendidikan karakter yang perlu ditanamkan sejak dini.

Menanamkan pendidikan karakter bisa melalui kegiatan belajar mengajar (Mashud, 2015). Dalam kegiatan pembelajaran berbagai mata pelajaran yang dapat menanamkan pendidikan karakter dan membentuk karakter bangsa, dari sekian banyaknya mata pelajaran salah satu diantaranya yang termasuk dapat menanamkan pendidikan karakter didalamnya adalah PPKn. Menurut Fauzi, et. al. (2013) muatan atau PPKn merupakan mata pelajaran yang sarat isi dengan nilai-nilai pancasila untuk membentuk sebuah kepribadian.

Pembelajaran PPKn bertujuan agar siswa diharapkan mampu memberikan penanaman untuk menumbuhkan dan mengembangkan rasa religius agar dapat berbakti kepada Tuhan Yang Maha Esa, mengembangkan rasa kekeluargaan didalam masyarakat, menjadikan seseorang memiliki jiwa nasionalisme yang tinggi dengan berjiwa demokratis serta berbudi pekerti yang luhur (Hamalik, 2013). Kualitas pembelajaran dapat dilihat dari dua sisi yang sama pentingnya yakni sisi proses dan hasil (Sanjaya, 2016)

Pada kenyataannya dilapangan dilihat pada hasil belajar siswa muatan PPKn semester genap pada tahun 2018/2019 73\% (11 orang) siswa kelas V SDN 3 Sungai Tiung Banjarbaru pada meteri Keberagaman Sosial Masyarakat Indonesia pada tahun tersebut mendapatkan nilai dibawah kriteria ketuntasan minimal yang sudah ditetapkan oleh sekolah atau belum tuntas, sedangkan 27\% (4 orang) siswa tuntas atau mendapatkan nilai diatas KKM. Untuk KKM di SDN 3 Sungai Tiung itu untuk kelas V adalah 70.

Permasalahan tersebut disebabkan karena pada saat pembelajaran kurangnya strategi dalam menyampaikan pembelajaran, pembelajaran yang hanya bersifat satu arah dan orientasi pembelajaran yang dilakukan siswa hanya mengingat (hapalan).

Apabila hal ini tidak diatasi, maka dampak yang akan diterima oleh siswa akan semakin besar, dimana siswa akan menjadi pribadi yang pasif, selalu menunggu informasi dan tidak tertarik untuk mencari tahu, sehingga siswa tidak mampu untuk mengembangkan kemampuan berpikir kritis dan kreatif, tidak mampu mengemukakan pendapatnya secara langsung. Dari aktivitas belajar siswa yang tidak bermutu tersebut pada akhirnya mengakibatkan pembelajaran tidak bermakna serta rendahnya hasil belajar siswa (Mashud, 2018). 
Berdasarkan permasalahan, penyebab dan dampak diatas, maka dibuatlah solusi untuk memecahkan masalah yakni, sebaiknya guru merancang kegiatan pembelajaran yang inovatif dan kreatif. Salah satunya menggunakan model pembelajaran. Oleh sebab itu maka dipilihlah kombinasi model pembelajaran CORP HORAY (Contekstual Teaching Learning, Role Playing, Course Review Horay) sebagai model pembelajaran yang mampu mngembangkan ketrampilan siswa berpikir kritis dan mengolah informasi yang didapat dalam pembelajaran serta dapat membuat suasana pembelajaran yang menyenangkan.

Model Pembelajaran CTL yaitu singkatan dari Contekstual Teaching Learning merupakan tipe model yang mengedepankan proses pembelajaran yang bersifat holistic dan memliliki tujuan untuk memicu anak lebih termotivasi menguasai materi yang dipelajarinya dan menghubungkan materi tersebut dengan orientasi kehidupan keseharian ditempat tinggalnya. Hal itu agar mereka berhasil memiliki pengetahuan maupun kemampuan yang dapat aplikasikan dari satu permasalahan ke permasalahan lainnya dikehidupan bermasyarakat (Shoimin, 2014) .

Selanjutnya model pembelajaran dipakai untuk menunjang model pembelajaran utama yaitu model pembelajaran yang dapat memberi siswa peluang untuk memerankan berbagai macam peran-peran didalamya dan meletakan diri mereka ke dalam sebuah kondisi sadar akan makna nilai kepercayaan terhadap diri sendiri maupun orang lain adalah bermain peran atau biasanya disebut Role Playing (Shoimin, 2014) .

Selanjutnya untuk model pelengkap dipilih sebuah model mengajar dengan ciri khas melakukan uji pemahaman materi yang sudah dipelajari anak menggunakan kotak bernomor yang akan diisi jawabannya, sedangkan untuk soal di bacakan oleh guru adalah model pembelajaran CRH. Siswa diperbolehkan berteriak horay apabila jawaban yang benar membentuk garis diagonal, horizontal maupun vertical (Shoimin, 2014).

Dengan menggunakan kombinasi model pembelajaran CORP HORAY (Contekstual Teaching Learning, Role Playing, Course Review Horay) memberikan cara baru dalam melakukan pembelajaran di kelas yang mampu membangun suasana kelas yang meriah. Dari model tersebut dapat melatih siswa berfikir secara kritis dalam pembelajaran, dapat memberikn siswa pengalaman langsung sehingga materi terasa mengesankan dan dapat memberikan siswa rasa kegembiraan serta sulit untuk dilupakan.

Rumusan masalah penelitian ini yaitu bagaimana aktvitas guru? apakah terdapat peningkatan aktivitas siswa? apakah terdapat peningkatan atas hasil belajar siswa pada materi keragaman sosial budaya masyarakat di Indonesia dengan menggunakan kombinasi model CORP HORAY di kelas V SDN 3 Sungai Tiung Banjarbaru?.

\section{METODE}

Pendekatan yang dipakai pada penelitian yang telah dilaksanakan ialah pendekatan kualitatif. Yakni pendekatan yang digunakan pada kondisi yang alamiah, peneliti sebagai kunci utama dimana analisis data bersifat induktif dan lebih menekankan pada makna daripada generalisasi (Sugiono, 2013).

Adapun jenis penelitian yang diterapkan dalam penelitian ini yaitu kepanjangan Penelitian Tindakan Kelas atau lebih dikenal dengan PTK. kegiatan pembelajaran pada penelitian ini bersifat reflektif, yang mempunyai tujuan untuk memperbaiki mutu 
pembelajaran, yang berdasarkan kepada pertimbangan rasional yang mantap dan valid, serta dilaksanakan dalam bentuk siklus berulang yang di dalamnya terbagi dalam empat tahapan utama kegiatan, tahap yang dimaksud yaitu perencanaan, tindakan, pengamatan, dan terakhir refleksi atau perbaikan (Arikunto, et. al., 2010).

Penelitian ini diterapkan pada kelas V SDN 3 Sungai Tiung. tahun ajaran 2019/2020. Adapun subjeknya yaitu kelas V berjumlah 15 orang siswa. Penelitian itu dilakukan pada muatan PPKn materi keragaman sosial budaya masyarakat Indonesia. Dalam penelitian, peneliti disini sebagai guru, mengumpul serta menafsir data. Instrumennya berupa lembar observasi guru, lembar observasi siswa dan lembar evaluasi. Lembar observasi diperoleh dari penggabungan langkah model CORP HORAY (Contekstual Teaching Learning, Role Playing and Course Review Horay).

Fokus penelitian yang dilakukan yakni guru, siswa serta hasil belajar siswa. Jenis data yang dipilih dalam penelitian ini yaitu data kualitatif dan kantitatif. Hasil observasi dari aktivitas guru dan aktivitas siswa dalam tahapan kegiatan pembelajaran menggunakan kombinasi Model CORP HORAY disebut jenis data kualitatif sedangkan skor test pada akhir pembelajaran yang dilakukan siswa disebut data kuantitatif. Instrument dalam penelitian untuk teknik pengukuran ini berupa test tertulis dimana berisi soal-soal tentang materi keberagaman sosial budaya masyarakat Indonesia.

Aktivitas guru dikatakan berhasil apabila kegiatan yang telah diukur dengan lembar observasi berhasil mendapat skor 30-36 dengan kriteria "sangat baik". Aktivitas siswa dikatakan berhasil apabila aktivitas yang telah diukur melalui observasi mencapai skor 21-24 dengan kriteria "sangat Aktif" dan mencapai $\geq 82 \%$ secara klasikal. Hasil belajar siswa secara individu dikatakan tuntas yakni apabila dapat mencapai nilai $\geq 70$ dan ketuntasan belajar klasikal dikatakan tuntas apabila telah mencapai persentase $\geq 82 \%$ melalui lembar evaluasi akhir.

\section{HASIL PENELITIAN}

\section{Pemaparan Data Siklus ke I}

Hasil pengamatan aktivitas guru yang telah dilakukan dalam kegiatan pembelajaran menggunakan kombinasi Model CORP HORAY (Contekstual Teaching Learning, Role Playing Dan Course Review Horay) terjadi peningkatan pada aktivitas guru dari siklus I pertemuan 1 sampai pertemuan 2. Untuk aktivitas guru pertemuan pertama ini guru telah meraih skor 29 dengan kriteria "baik", untuk aktivitas guru pertemuan kedua ini meningkat dan guru meraih skor 32 dengan dapat kriteria "sangat baik". Di bawah ini merupakan hasil pengamatan aktivitas guru pertemuan pertama sampai pertemuan kedua :

Tabel 1. Kecendrungan Aktifitas Guru

\begin{tabular}{ccc}
\hline Pertemuan & Skor & Kriteria \\
\hline 1 & 29 & Baik \\
2 & 32 & Sangat Baik \\
\hline
\end{tabular}

Selanjutnya hasil observasi aktivitas siswa yang sudah terlaksana pada siklus I, juga terjadi peningkatan pada aktivitas siswa dari pertemuan pertama sampai pertemuan kedua. Untuk aktivitas siswa pertemuan pertama mendapat persentase aktivitas siswa sebesar 52\% 
serta kriteria "cukup aktif" dan pada pertemuan kedua mendapat persentase aktivitas siswa meningkat sebesar 67\% serta kriteria "aktif". Di bawah ini merupakan hasil kecendrungan aktivitas siswa pertemuan pertama sampai pertemuan kedua:

Tabel 2. Kecendrungan Aktifitas Siswa

\begin{tabular}{ccc}
\hline Pertemuan & Persentasi & Kriteria \\
\hline 1 & $52 \%$ & Cukup Aktif \\
2 & $67 \%$ & Aktif \\
\hline
\end{tabular}

Hasil belajar siswa tiap pertemuan baik individu maupun klasikal semakin meningkat dengan mengggunakan kombinasi model CORP HORAY. Pada Aspek kognitif (pengetahuan) pada pertemuan I siswa yang tuntas mencapai 44\%, kemudian pada pertemuan II mencapai 59\%. Pada aspek afektif (sikap) Pada pertemuan 1 siswa yang tuntas pada aspek afektif mencapai 44\%, pertemuan II 74\%. Pada aspek psikomotor (keterampilan) Pada pertemuan 1 ketuntasan siswa pada aspek psikomotorik mencapai 37\%, pertemuan 2 meningkat dengan signifikan hingga mencapai $67 \%$. Berikut merupakan hasil belajar siswa pertemuan pertama sampai pertemuan kedua:

Tabel 3. Kecendrungan Hasil Belajar Siswa

\begin{tabular}{cccc}
\hline Pertemuan & Kognitif & Afektif & Psikomotori \\
\hline 1 & $44 \%$ & $44 \%$ & $37 \%$ \\
2 & $59 \%$ & $74 \%$ & $67 \%$ \\
\hline
\end{tabular}

\section{Pemaparan Data Siklus ke II}

Hasil pengamatan Pada Siklus II, aktivitas guru yang telah dilakukan dalam kegiatan pembelajaran menggunakan kombinasi Model CORP HORAY (Contekstual Teaching Learning, Role Playing and Course Review Horay) terjadi peningkatan aktivitas guru dari pertemuan 3 sampai pertemuan 4. Untuk aktivitas guru pertemuan ketiga meraih skor 34 dapat kriteria "sangat baik" dan untuk pertemuan keempat kembali meningkat dan meraih skor 35 dengan kriteria "sangat baik". Di bawah ini merupakan hasil pengamatan aktivitas guru pertemuan ketiga sampai pertemuan empat:

Tabel 4. Kecendrungan Aktifitas Guru

\begin{tabular}{ccc}
\hline Pertemuan & Skor & Kriteria \\
\hline 3 & 34 & Sangat Baik \\
4 & 35 & Sangat Baik \\
\hline
\end{tabular}

Selanjutnya hasil observasi aktivitas siswa yang sudah terlaksana, juga terjadi peningkatan pada aktivitas siswa dari pertemuan ketiga sampai pertemuan keempat, hal demikian dikarenakan pada setiap pertemuan semakin banyaknya siswa yang aktif dan disetiap pertemuan siswa memahami pembelajaran yang berlangsung dan dapat beradaptasi dengan pembelajaran menggunakan model CORP HORAY ini. Selain itu peningkatan aktivitas siswa pada setiap pertemuannya juga ada kaitannya dari aktivitas guru yang mengalami peningkatan disetiap pertemuan. Aktivitas siswa pertemuan ketiga dengan persentase ketuntasan klasikal 78\% serta kriteria "aktif" dan meningkat sebersar 95\% pada pertemuan 
keempat serta kriteria "sangat aktif". Dibawah ini merupakan hasil kecendrungan aktivitas siswa pertemuan ketiga sampai pertemuan empat:

\begin{tabular}{ccc}
\multicolumn{3}{c}{ Tabel 5. Kecendrungan Aktifitas Siswa } \\
\hline Pertemuan & Persentasi & Kriteria \\
\hline 3 & $78 \%$ & Aktif \\
4 & $95 \%$ & Sangat Aktif \\
\hline
\end{tabular}

Hasil belajar siswa tiap pertemuan baik individu maupun klasikal semakin meningkat dengan mengggunakan kombinasi model CORP HORAY. Pada Aspek kognitif (pengetahuan) pada pertemuan 3 mencapai 78\%, dan pada pertemuan 4 mencapai 96\%. Pada aspek afektif (sikap) pertemuan 3 sebesar 85\%, dan pertemuan 4 mencapai 93\%. Pada aspek psikomotor (keterampilan) pertemuan 3 mencapai 89\%, dan pada pertemuan 4 mencapai 96\%. Berikut merupakan hasil belajar siswa pertemuan ketiga sampai pertemuan empat:

Tabel 6. Kecendrungan Hasil Belajar Siswa

\begin{tabular}{cccc}
\hline Pertemuan & Kognitif & Afektif & Psikomotor \\
\hline 3 & $78 \%$ & $85 \%$ & $89 \%$ \\
4 & $96 \%$ & $93 \%$ & $96 \%$ \\
\hline
\end{tabular}

\section{Perbandingan Data Setiap Siklus}

Terjadi peningkatan perolehan aktivitas guru, siswa, sampai hasil belajar disetiap pertemuannya. Hasil observasi akan aktivitas guru pertemuan 1-4 terjadi peningkatan karena pada setiap pertemuan guru selalu melakukan refleksi atau perbaikan setelah pembelajaran dan selalu memperhatikan kekurangan dan aspek-aspek yang ditingkatkan sehingga pada pertemuan penelitian selanjutnya mengalami peningkatan.

Dari hasil penelitian yang telah dilaksanakan dikelas V SDN 3 Sungai Tiung dapat dilihat pada grafik kecendrungan seluruh aspek yang diteliti pada gambar berikut:

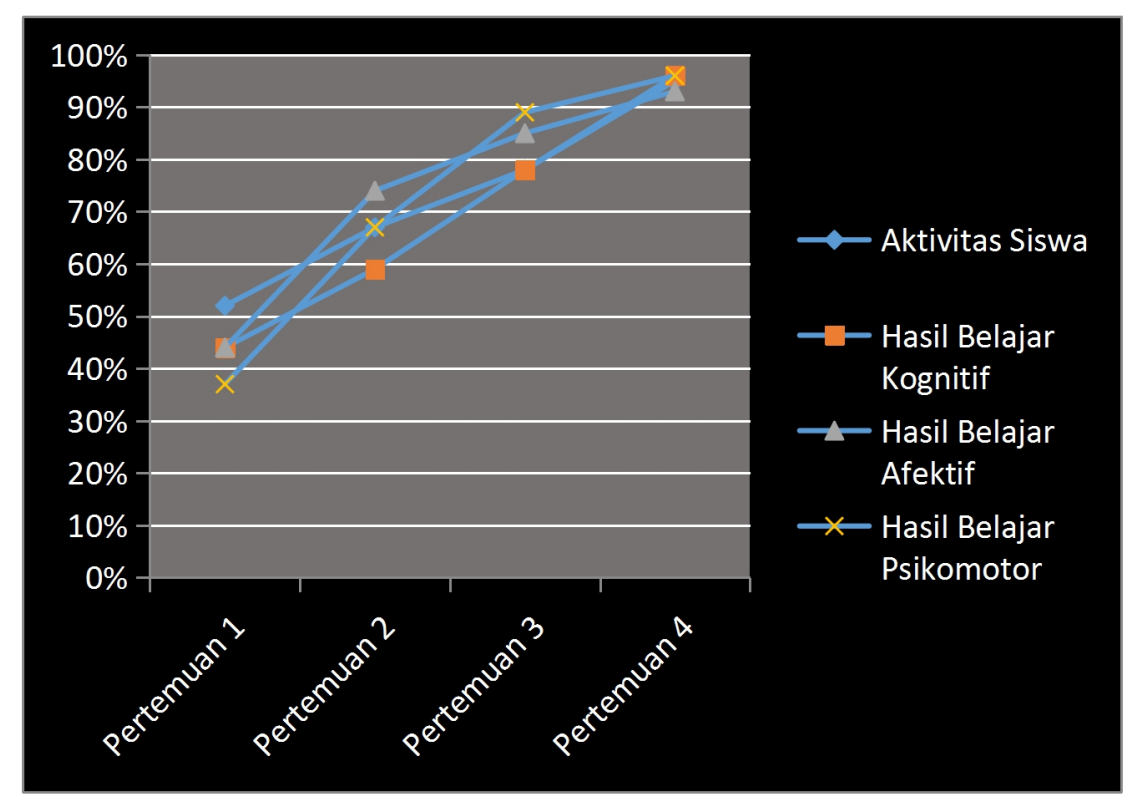

Gambar 1. Kecendrungan Aspek 
Dapat ditarik benang merah atau kesimpulan bahwa terjadi peningkatan aktivitas guru pada setiap pertemuannya. Peningkatan pada aktivitas guru tersebut berhubungan dengan aktivitas siswa dalam proses pembelajaran yang berpengaruh juga terhadap peningkatan hasil belajar disetiap pertemuanya. Hal ini membuktikan bahwa terdapat korelasi antara aktivitas guru, siswa juga hasil belajar. Semakin guru dapat meningkatkan aktivitas maka semakin meningkat pula aktivitas siswa, dan apabila siswa terlihat aktif di dalam mengikuti pembelajaran maka hasil belajar anak pun dapat meningkatkan dan semakin baik pula.

\section{PEMBAHASAN}

Dari penelitian yang telah dilaksanakan terlihat dengan menggunakan kombinasi Model CORP HORAY pada Tema Lingkungan Sahabat Kita materi keberagaman sosial budaya masyarakat Indonesia dapat meningkatkan kualitas dalam pembelajaran. Selama proses pembelajaran yang telah dilaksanakan dikelas V SDN 3 Sungai Tiung Banjarbaru siswa menjadi lebih bersemangat ikut serta dalam mengikuti kegiatan pembelajaran dan berdampak pada meningkatnya hasil belajar siswa. Aktivitas guru, aktivitas siswa serta hasil belajar mengalami peningkatan baik pertemuan I sampai pertemuan IV.

Bersumber dari hasil analisis data yang dilakukan selama penelitian berlangsung dapat diketahui bahwasanya, aktivitas guru mengalami kecendrungan peningkatan. Keberhasilan saat guru melakukan aktivitas guru melaksanakan kombinasi model CORP HORAY (Contekstual Teaching Learning, Role Playing and Course Review Horay). Peningkatan tersebut disebabkan karena guru berupaya melakukan perbaikan pada tiap-tiap pertemuannya. Hal tersebut berlangsung karena setelah selesai melakukan kegiatan pembelajaran guru membuat dan melakukan refleksi atau rekondisi terhadap kegiatan pembelajaran yang sudah dilaksanakan pada setiap pertemuannya sehingga tujuan yang sudah dirumuskan dapat tercapai dan meperbaiki kekurangan yang terjadi didalam pembelajaran. Sesuai dengan pendapat Uno \& Mohammad (2015) yang menyatakan peningkatan kualitas pembelajaran dengan inovasi pembelajaran merupakan usaha yang dilakukan guru agar dapat meningkatkan dan mengembangkan aktivitas anak dalam proses pembelajaran serta hasil belajar agar yang diharapkan dapat dicapai. Didukung pendapat menurut Suriansyah (2014:58) guru ialah penentu terlaksananya sebuah strategi dalam kegiatan belajar didalam kelas. Aktivitas serta hasil belajar siswa sangat responsive terhadap peran seorang guru didalam kelas (Mashud, 2020). Guru memegang tanggung jawab untuk memerhatikan segala sesuatu yang terjadi di dalam kelas guna membantu proses perkembangan siswa hal ini sependapat dengan Indra Jati dalam Suriansyah (2014) yang mengajukan bahwa, guru masa depan tidak hanya terampil sebagai pengajar (Teacher), tetapi juga sebagai pelatih (Coach), pembimbing (Counselor), serta manajer belajar (Learning Manajer).

Sebagai faktor penentu dalam keberhasilan suatu proses pembelajaran guru untuk dituntut makin kreatif dan inovatif agar suasana belajar menjadi terasa menyenangkan sehingga siswa antusias dan bersemangat didalamnya. Perihal tersebut sependapat dengan Sanjaya (2013:139-140) guru dituntut kreatif dan inovatif agar mampu menyesuaikan kegiatan mengajar dengan gaya dan karakteristik siswanya. 
Bersumber pada hasil analisis data aktivitas siswa selama penelitian ini menemukan bahwa dalam aktivitas siswa mengalami peningkatan pada pertemuan I sampai pertemuan IV. Peningkatan pada kreativitas siswa ini terjadi karena siswa terlibat aktif dalam proses kegiatan pembelajaran. Peningkatan ini terjadi karena adanya peningkatan aktivitas guru dimana guru melakukan inovasi dengan menggunakan pembelajaran kooperatif dalam kegiatan pembelajaran yang sangat berpengaruh pada aktivitas dan hasil belajar siswa. Menurut Ruhimat, et. al. (2015) Aktivitas siswa dalam kegiatan pembelajaran memiliki peran yang amat krusial, hal itu disebabkan pembelajaran bertujuan untuk merubah perilaku siswa. Hal ini sesuai dengan pendapat Kunandar (2011:277) bahwa keterlibatan siswa dalam proses belajar mengajar dapat menunjang keberhasilan.

Hasil belajar siswa pada pertemuan pertama hingga pertemuan ke empat juga mengalami peningkatan baik secara individu siswa maupun secara klasikal. Hal ini terjadi disebabkan siswa sudah mampu mencapai tujuan pembelajaran yang sudah direncanakan dan diharapkan. Peningkatan ini juga terjadi dikarenakan penggunaan sebuah kombinasi model pembelajaran yang diimplementasikan oleh guru. Salah satu faktor ekternal dapat mempengaruhi hasil belajar siswa adalah guru itu sendiri. Hal tersebut sependapat dengan Suriansyah, et. al. (2014) bahwa guru tidak hanya berperan sebagai model atau panutan bagi siswa yang diajarnya, tetapi juga sebagai pengelola pembelajaran (manager of Learning). Dengan begini, keberhasilan suatu proses pembelajaran sangat ditentukan oleh kompetensi guru.

Berdasarkan hal diatas maka hipotesis yang diajukan dalam penelitian ini yang berbunyi "Jika Pembelajaran Materi Keragaman Sosial Budaya Masyarakat Indonesia Menggunakan Kombinasi Model CORP HORAY (Contekstual Teaching Learning, Role Playing Dan Course Review Horay), maka aktivitas belajar siswa yang berdampak pada hasil belajar siswa kelas V SDN 3 Sungai Tiung Banjarbaru akan meningkat" dapat diterima.

\section{SIMPULAN}

Kesimpulan bersumber dari hasil penelitian tindakan kelas yang dilakukan terhadap siswa kelas V SDN 3 Sungai Tiung Banjarbaru menggunakan model kombinasi model CORP HORAY adalah meningkatnya seluruh aspek yang diteliti hal ini dapat dilihat sebagai berikut:

Aktivitas guru dapat terlaksana sesuai rencana pada setiap pertemuannya sehingga memperoleh kriteria sangat baik dan tercapainya indikator keberhasilan yang telah ditetapkan peneliti. Aktivitas siswa dalam melakukan kegiatan belajar dapat terlaksana sesuai rencana pada setiap pertemuannya sehingga memperoleh kategori sangat aktif dan telah mencapai indikator yang telah ditetapkan peneliti dan untuk hasil belajar siswa telah mengalami kenaikan disetiap pertemuanya. Hal demikian tampak dari siswa telah mampu mencapai indikator ketuntasan yang telah ditetapkan, baik ketuntasan secara individual maupun secara klasikal.

\section{DAFTAR PUSTAKA}

Arikunto, S. 2014. Penelitian Tindakan Kelas, Jakarta: Bumi aksara.

Arikunto, S., Suhardjono, \& Supardi. 2010. Penelitian Tindakan Kelas, Jakarta: Bumi Aksara. 
Fauzi, F. Y., Arianto, I., \& Solihatin, A. 2013. Peran Guru Pendidikan Pancasila Dan Kewarganegaraan Dalam Upaya Membentuk Karakter Peserta Didik. Jurnal PPKN UNJ, $I(2), 1-15$.

Hamalik, O. 2015. Kurikulum dan Pembelajaran, Jakarta: Bumi Aksara.

Hamalik, O. 2013. Proses Belajar Mengajar. Jakarta: PT Bumi Aksara.

Kunandar. 2011. Guru Profesional, Jakarta: Rajawali Pers

Mashud, M. (2015). Pendekatan Pembelajaran Pendidikan Jasmani Olahraga dan Kesehatan di Era 21. Jurnal Multilateral, 14(2), 89-196. https://doi.org/10.20527/multilateral.v14i2.2471.g2172

Mashud, M. (2018). Analisis Masalah Guru PJOK Dalam Mewujudkan Tujuan Kebugaran Jasmani. Multilateral Jurnal Pendidikan Jasmani Olahraga, 17(2), 77-85. https://doi.org/10.20527/multilateral.v17i2.5704

Mashud, M. (2020). The Effectiveness of Physical Education Learning in Elementary School Located in Wetland Environment. Jurnal Pendidikan: Teori, Penelitian, Dan Pengembangan, 5(2), 265-270. https://doi.org/DOI: http://dx.doi.org/10.17977/jptpp.v5i2.13194

Sanjaya, W.2016. Penelitian Tindakan Kelas. Jakarta : Prenada Media.

Shoimin, A. 2014. 68 Model Pembelajaran Inovatif dlam Kurikulum 2013, Yogjakarta: Ar-Ruzz Media.

Sugiyono. 2013. Penelitian Kuantitatif, Kualitatif dan $R \& D$, Bandung: Alfabeta.

Suriansyah, A., Aslamiah, Sulaiman, \& Noorhafizah. 2014. Strategi Pembelajaran, Jakarta: Raja Grafindo Persada.

Tilaar. 2005. Manifesto Pendidikan Nasional Tinjauan dari Perspektif Postmodemisme dan Studi Kutural, Jakarta: Kompas. 